\title{
Evolução Tectono-Metamórfica da Formação Morro do Campo na Serra dos Martírios- Andorinhas, domínio norte do Orógeno Araguaia
}

\section{Bruna Maria Cruz Fernandes*, Vinícius Tieppo Meira}

\section{Resumo}

O Orógeno Araguaia tem-se mostrado importante nos debates para reconstituições das eras Arqueana e Proterozoica, já que possui rochas dessas idades. Sua formação é vinculada aos processos de amalgamação do supercontinente Gondwana durante o Ciclo Orogênico Brasiliano/Pan-Africano no Neoproterozoico. A Serra dos Martírios-Andorinhas faz parte desse orógeno e é sustentada por rochas quartzíticas da Formação Morro do Campo, porção basal do Supergrupo Baixo Araguaia. Em seu entorno ocorrem xistos da Formação Xambioá. Localmente a Formação Morro do Campo está sobreposta à Formação Xambioá, caracterizando uma inversão estratigráfica marcada a sudoeste pela Zona de Cavalgamento Andorinhas. Análises cinemáticas preliminares sugerem movimentação de topo para NW. Em geral, as estruturas planares na Serra dos Martírios-Andorinhas, incluindo acamamento, foliação e planos de falhas fotointerpretadas, estão orientadas na direção NW-SE, paralelas à Zona de Cavalgamento Andorinhas.

\section{Palavras-chave: \\ Orógeno Araguaia, Formação Morro do Campo, Serra dos Martírios-Andorinhas}

\section{Introdução}

O Orógeno Araguaia é constituído por rochas metamórficas para e ortoderivadas e complexos máficoultramáficos. Dentre as unidades que o compõe, o Supergrupo Baixo Araguaia é responsável pela sustentação da Serra dos Martírios-Andorinhas (Goyareb et al., 2008), com as Formações Morro do Campo e Xambioá, ambas pertencentes, respectivamente, à base a ao topo do Grupo Estrondo.

Segundo Gorayeb et al. (2008) a Formação Morro do Campo é constituída por quartzitos intercalados por xistos com quantidades de mica variadas $e$, subordinanadamente, metaconglomerados. Os mesmos autores descrevem a Formação Xambioá como constituída por xistos que podem conter carbonatos, granada, cianita, estaurolita e/ou fibrolita.

A Formação Morro do Campo ocorre estratigraficamente abaixo da Formação Xambioá, mas na porção sudoeste da Serra dos Martírios-Andorinhas ela ocorre sobreposta à Formação Xambioá, caracterizando uma inversão estratigráfica, delimitada pela Zona de Cavalgamento Andorinhas (Goyareb et al., 2008).

Este trabalhou visou estudar as características estruturais da Serra dos Martírios-Andorinhas, buscando contribuir no entendimento da evolução do Orógeno Araguaia no contexto do Ciclo Orogênico Brasiliano/PanAfricano.

\section{Resultados e Discussão}

Em campo foram separados três litotipos: quartzito, biotita-quartzo xisto e mica-clorita-quartzo xisto. Os quartzitos possuem variadas concentrações de mica, sendo a foliação principal $S_{n}$ definida principalmente pela muscovita. Os quartzitos sustentam o relevo da Serra dos Martírios-Andorinhas, enquanto as rochas mais micáceas, ocorrem nas áreas mais rebaixadas.

Em seção delgada foram separados dois tipos de rochas: quartzito possuindo variadas quantidades de minerais opacos (magnetita e ilmenita) e com zircão e feldspato potássico como acessórios; e xisto possuindo variadas quantidades de micas (biotita e muscovita) e calcita/dolomita e com turmalina e clorita como acessórios. Os grãos de quartzo das rochas estudadas mostram diferentes texturas vinculadas a estágios distintos de deformação dinâmica e de recuperação.

Tanto em campo e amostra de mão quanto em seção delgada foi possível verificar indicadores cinemáticos com movimentação de topo para NW. Descrições de outros trabalhos corroboram tal movimentação. As maiores estruturas do mapa possuem direção NW-SE e incluem acamamento, foliação principal $S_{n}$ e falhas fotointerpretadas. Considerando a orientação geral das lineações de estiramento e mineral NW-SE na região estudada, associada à cinemática observada, a Zona de Cavalgamento Andorinhas seria compatível com uma zona de cisalhamento sinistral com componente inverso.

\section{Conclusões}

A estruturação da Serra dos Martírios-Andorinhas possui orientação geral NW-SE, a qual inclui acamamento sedimentar preservado, foliação penetrativa $S_{n}$ e zonas de cisalhamento. As lineações de estiramento e mineral são predominantemente orientadas NW-SE e indicadores cinemáticos sugerem movimentação de topo para NW.

Na porção norte da serra, a forma ovalada definida pelo acamamento/foliação principal definem uma estrutura dômica, com relação estratigráfica normal das formações Morro do Campo, na base, e Xambioá, no topo. Na porção sudoeste da serra, a chamada "Zona de Cavalgamento Andorinhas", que inverte localmente a estratigrafia da região, possui movimentação principal transcorrente sinistral com componente inverso subordinado.

\section{Agradecimentos}

Muito obrigada aos meus pais, amigos e, sobretudo, ao meu orientador pela paciência e risadas. Também obrigada ao CNPq pela confiança de financiar o projeto.

Goyareb, P. S. de S.; Moura, C. A. V.; Abreu, F. de A. M. de. Geologia do Parque Estadual da Serra dos Martírios-Andorinhas e região adjacente. In: Parque Martírios-Andorinhas: conhecimento, história e preservação. Belém: EDUFPA, 2008. 